\title{
Transfusion and risk of infection in Canada: UPDATE 2004
}

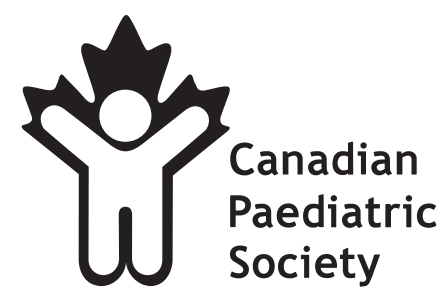

I Canada and other countries, many steps are taken to minimize the risk of infection through the transfusion of blood or blood products (1). However, the infection risk can never be zero because these are biological products taken from living donors who are never 'germ free' (2). This is in contrast to drugs that can be manufactured de novo under sterile conditions in a laboratory. The present note provides an update on transfusion infection risks in Canada. It replaces the 2003 note (3), and may be helpful to practitioners in discussions with patients and parents toward obtaining informed consent before blood or blood product administration.

While any infectious agent that has a blood phase has the potential to be transmitted by transfusion of blood or blood products, the probability of infection in the recipient depends on a number of factors, including (4):

- the prevalence of the agent in the blood of the donor population;

- the tolerance of the agent to blood handling, storage and manufacturing procedures;

- the infectivity and pathogenicity of the agent;

- the recipient's health status; and

- the effectiveness of donor screening or donor testing for the agent.

The importance of these factors is well illustrated by the tale of West Nile virus (WNV). WNV has only recently been introduced into the North American bird population and, through secondary transmission via mosquitoes, to humans $(5,6)$. Not surprisingly, given the blood phase of infection, WNV was shown in 2002 to be transmissible by blood (7), with an estimated mean risk of $2 / 10,000$ to $5 / 10,000$ (maximum 21/10,000) in outbreak regions in the United States (8). This resulted in rapid efforts to develop a screening test to detect WNV infection in blood donors (9). Both the Canadian Blood Services and Héma-Québec started testing for WNV infection in June 2003, using a new test that has an estimated sensitivity of $75 \%$ to $90 \%$ to detect infected donors during the WNV season. The seasonal variation in the transmission of WNV from mosquitoes to humans means that the prevalence of acute infection among blood donors varies. Surveillance through the new screening programs for blood donors last year found marked variation in the prevalence of WNV infection across the country, as well as variation in the onset of the 'season' for WNV in different regions. The background risk of
WNV in unscreened blood is predicted to change over the next few years as the bird population becomes immune, resulting in decreased transmission from the avian population to mosquitoes and to people. With WNV donor screening testing now in place, the risk of contamination in blood collected from donors during a WNV outbreak is now estimated to be $1 / 100,000$ to $3 / 100,000$. This measure reflects the sensitivity of the test and the prevalence of infection among donors in a given region.

This past season, the blood donor WNV screening program has had the added benefit of providing public health authorities with a marker for infection rates among local and regional populations. Public health authorities in most jurisdictions now provide regular updates concerning the penetration of WNV in birds, animals and humans in Canada during the mosquito season. In the same way that Canadians monitor the Weather Channel, health care practitioners need to monitor the 'Web-based public health channels' through their local public health unit, a provincial or territorial health Web site or via Health Canada's West Nile Monitor (10), to gain a sense of the background risk for WNV in their region.

In Canada, the infectious disease risks of transfusion are minimized through multiple steps, including: blood collection from volunteer unpaid donors, donor interview and selection procedures, donor screening by serological and other tests (Table 1), and viral inactivation procedures included in the

\section{TABLE 1}

Testing of blood donors in Canada* by Canadian Blood Services (CBS) and Héma-Québec

\begin{tabular}{ll}
\hline HIV-type 1/2/0 $\mathbf{0}^{\dagger}$ group & Antibody/NAT \\
\hline HBV & Hbs Ag, Anti-HBc ${ }^{\ddagger}$ \\
HTLV type I/II & Antibody \\
Syphilis & Nontreponemal test - Treponemal test/PK-TP \\
HCV & Antibody/NAT \\
WNV & NAT \\
Other & CMV antibody on selected units only \\
\hline
\end{tabular}

*Personal communications: Dr Gilles Delage, Héma-Québec; Dr Heather Hume, CBS. Héma-Québec and CBS are developing bacterial culture testing for thrombopharesis platelets; tWhile the newer PRISM human immunodeficiency virus (HIV) antibody test does detect HIV group $O$, donors are still asked questions related to travel to parts of the world where HIV-O infection is prevalent, until a change in practise is approved; ${ }^{\ddagger}$ Antibody to hepatitis $B$ core antigen $(A n t i-H B c)$ testing has been introduced by Héma-Québec in 2003 and will be introduced by CBS in late 2004; §Héma-Québec and CBS are developing bacterial culture testing for thrombopharesis platelets. CMV Cytomegalovirus; Hbs Ag Hepatitis B surface antigen; HBV Hepatitis B virus; HCV Hepatitis C virus; HTLV Human T-lymphotropic viruses; NAT Nucleic acid testing; WNV West Nile Virus 
TABLE 2

Specific manufacturing procedures for virus inactivation or removal

\begin{tabular}{lll}
\hline Procedure & Agents inactivated & Agents not inactivated \\
\hline Inactivation by heat & $\mathrm{CMV}, \mathrm{HAV}, \mathrm{HBV}, \mathrm{HCV}, \mathrm{HIV}$, WNV, Parvovirus B19 \\
Inactivation by solvent/detergent & $\mathrm{CMV}, \mathrm{HBC}, \mathrm{HCV}, \mathrm{HIV}$, WNV \\
Ultrafiltration using $35 \mathrm{~nm}$ and $15 \mathrm{~nm}$ filters & Removes even small viruses but also macromolecules \\
Leukocyte depletion & eg, Factor VIII is decreased & HAV, Parvovirus B19, enteroviruses \\
\hline
\end{tabular}

CMV Cytomegalovirus; HAV Hepatitis A virus; HBV Hepatitis B virus; HCV Hepatitis C virus; HIV Human immunodeficiency virus; HTLV Human T-lymphotropic viruses; WBC White blood cell; WNV West Nile virus

TABLE 3

Manufacturing steps to decrease infectious risks of plasma preparations and plasma-derived components

\begin{tabular}{|c|c|c|c|}
\hline Plasma preparation & $\begin{array}{c}\text { Virus risk } \\
\text { pre-inactivation } \\
\text { process(es) }\end{array}$ & $\begin{array}{c}\text { Pools screened } \\
\text { for HIV, HCV, HBV, } \\
\text { and HTLV type I, II* }\end{array}$ & Further virus inactivation steps \\
\hline Cryoprecipitate & ++ & yes & nonet $^{\dagger}$ \\
\hline Factor VII & + & yes & heat inactivation \pm solvent/detergent \\
\hline Factor VIII & + & yes & heat inactivation \pm solvent/detergent \\
\hline Factor IX & + & yes & heat inactivation, solvent/detergent, chromatography \\
\hline Antithrombin concentrates & + & yes & COHN fractionation, heat inactivation \\
\hline Albumin & + & yes & heat inactivation \\
\hline IVIG products & + & yes & $\begin{array}{l}\text { COHN fractionation, } \pm \text { hydrolase, } \pm \text { solvent/detergent, } \pm \text { heat inactivation, } \\
\pm \text { chromatography, nanofiltration }\end{array}$ \\
\hline IMIG & + & yes & $\mathrm{COHN}$ fractionation, solvent/detergent, heat treatment, nanofiltration, \pm chromatography \\
\hline Specific antibody products $\ddagger$ & + & yes & $\begin{array}{l}\mathrm{COHN} \text { fractionation or ion exchange column chromatography, solvent/detergent, } \\
\text { filtration } \pm \text { heat inactivation }\end{array}$ \\
\hline
\end{tabular}

*Human T-lymphotropic viruses (HTLV) type I/II are cell-associated viruses, so they are not found in manufactured plasma-derived products and serological screening of source plasma is not required. Similarily, cytomegalovirus (CMV) is primarily cell-associated and the manufacturing processes remove risk; thence the risk of transmission of infection from cryoprecipitate is similar to the risk from blood and blood products, and greater than from plasma-derived manufactured products; $\ddagger$ g, Hepatitis B (HBV) immune globulin, Tetanus Immune globulin, Rabies Immune globulin, Rh (D) immune globulin, etc. HCV Hepatitis C virus; HIV Human immunodeficiency virus; IMIG Intramuscular immunoglobulin; IVIG Intravenous immunoglobulin

\section{TABLE 4}

Bacterial agents associated with acute infection during blood product transfusion

\begin{tabular}{lrl}
$\begin{array}{l}\text { Blood } \\
\text { component }\end{array}$ & \multicolumn{1}{c}{ Storage } & Bacterial agent \\
\hline $\begin{array}{l}\text { Packed } \\
\text { red cells }\end{array}$ & $1^{\circ} \mathrm{C}$ to $6^{\circ} \mathrm{C}$ for 35 to 42 days & $\begin{array}{l}\text { Yersinia enterocolitica } \\
\text { Gram-negative, including } \\
\text { Pseudomonas species }\end{array}$ \\
Whole blood & $1^{\circ} \mathrm{C}$ to $6^{\circ} \mathrm{C}$ for 35 to 42 days & Gram-negative organisms \\
Platelets & $20^{\circ} \mathrm{C}$ to $24^{\circ} \mathrm{C}$ for 5 days & Skin flora (eg, Staphylococcus \\
& & $\begin{array}{l}\text { epidermidis Diptheroids) } \\
\text { Salmonella species }\end{array}$ \\
& & Escherichia coli \\
& & Enterococci species \\
& & Clostridium species \\
& & Serratia marcescens \\
& & Staphylococcus aureus \\
Plasma & $18^{\circ} \mathrm{C}$, thawed, & Pseudomonas aeruginosa \\
\hline
\end{tabular}

manufacturing of plasma-derived products (Table 2) (11-14). As noted in Table 2, solvent/detergent procedures dissolve the lipid envelope of the human immunodeficiency virus, WNV, hepatitis $B$ virus and hepatitis $C$ virus, but are not effective against nonlipid enveloped viruses such as hepatitis $\mathrm{A}$ virus or parvovirus B19. Heat inactivation is effective against a wide range of viruses, including $\mathrm{WNV}$, hepatitis $\mathrm{A}$ virus and parvovirus (14). The leukocyte reduction technique that is used by Canadian Blood Services and Héma-Québec to further improve the safety of the blood supply also reduces the infection transmission risk, particularly for cytomegalovirus (CMV) (13). Table 3 identifies specific inactivation steps in the manufacture of different plasma-derived products that decrease viral infection risks.

Unfortunately, the solvent/detergent and heat inactivation procedures noted in Table 2 cannot be used on red blood cells or platelets, because neither can withstand these vigorous viral inactivation processes. Pathogen reduction techniques suitable for these labile blood components are in development and, in some cases, being tested in clinical trials.

Almost all reported acute infectious complications arising from blood product transfusion are associated with bacterial pathogens $(15,16)$ (Table 4$)$. While the use of closed multicomponent plastic blood pack collection systems has helped to decrease the problem, contamination of platelet concentrates is still a concern (16). The risk of bacterial contamination of frozen components such as fresh frozen plasma and cryoprecipitates is now very low, because the usual microbes (Table 4) are killed by freezing and other storage conditions. Where plasma has been found to be the source of infection, this was usually due to contamination of the water bath used to thaw the product (17). The use of microwave techniques specifically designed for this purpose minimizes this risk. 


\section{TABLE 5}

Estimated risk of infectious agent blood or blood products

\begin{tabular}{|c|c|c|c|}
\hline $\begin{array}{l}\text { Agents and } \\
\text { products }\end{array}$ & $\begin{array}{l}\text { Transfusion- } \\
\text { transmitted }\end{array}$ & Pathogenic & $\begin{array}{l}\text { Canadian estimated } \\
\text { risk of contamination }\end{array}$ \\
\hline \multicolumn{4}{|c|}{ Viruses for which all blood donors are tested } \\
\hline $\mathrm{HIV}^{\dagger}$ & Yes & Yes & $<1 / 4,000,000$ \\
\hline $\mathrm{HCV}^{\dagger}$ & Yes & Yes & $<1 / 1,000,000$ \\
\hline $\mathrm{HBV}^{\dagger}$ & Yes & Yes & $1 / 275,000$ to $1,000,000$ \\
\hline $\begin{array}{l}\mathrm{HTLV}^{\dagger} \\
\text { types I and II }\end{array}$ & Yes & Yes & $<1 / 4,000,000$ \\
\hline
\end{tabular}

$\begin{array}{lccc}\begin{array}{l}\text { Other viruses } \\ \text { CMV }\end{array} & \text { Yes } & \text { Yes } & \begin{array}{l}\text { risks vary with donor/ } \\ \text { recipient }^{\ddagger}\end{array} \\ \text { Parvovirus B19 } & \text { Yes } & \text { Yes } & 1 / 10,000 \text { to } 1 / 15,000 \\ \text { GBV-C } & \text { Yes } & \text { Unknown } & 1-2 \text { in 100; not pathogenic } \\ \text { TTV }^{\dagger} & \text { Yes } & \text { Unknown } & 1 / 100 \text {; rarely pathogenic } \\ \text { SEN-V }{ }^{\dagger} & \text { Yes } & \text { Unknown } & 1 / 00 \text {; not pathogenic } \\ \text { HHV-8 }{ }^{\dagger} & \text { Unknown } & \text { Yes } & \text { Unknown } \\ \text { WNV } & \text { Yes } & \text { Yes } & 1-3 / 100,000 \text { during } \\ & & & \text { outbreak }\end{array}$

$\begin{array}{lccc}\begin{array}{l}\text { Parasites } \\ \text { Malaria }\end{array} & \text { Yes } & \text { Yes } & \begin{array}{c}4 \text { cases reported in } \\ \text { Canada in last } 10 \text { years }\end{array} \\ \begin{array}{l}\text { Chagas } \\ \text { (Trypanosoma cruzi) }\end{array} & \text { Yes } & \text { Yes } & 2 \text { cases reported in } \\ \text { Canada in last } 15 \text { years } \\ \begin{array}{l}\text { Babesiosis } \\ \text { (Babesia microti) }\end{array} & \text { Yes } & \text { Yes } & \begin{array}{c}1 \text { case reported in Canada } \\ \text { in last } 15 \text { years }\end{array}\end{array}$

Prion

vCJD Unknown Yes theoretical risk of $<1 / 10,000,000$

${ }^{*}$ Risk of contamination refers to the potential residual risk of infection from the listed organisms in blood or blood products after proper screening and manufacturing processes have occurred; ' ${ }^{\dagger}$ Based on $3 \%$ to $5 \%$ of the Canadian population from the 17 to 65 years age group being blood donors. Based on reported cases from Public Health. Based on sensitivity and specificity of the tests used at Canadian Blood Services and Héma-Québec; ${ }^{\ddagger}$ Cytomegalovirus (CMV) infection risk is decreased by leukoreduction procedures (see text); $\S$ West Nile virus risk of 1-3/100,000 during an outbreak is an estimation given the sensitivity of the screening test and the prevalence of donor infection during an outbreak. HBV Hepatitis B virus; HCV Hepatitis C virus; GBV-C formerly named Hepatitis G virus: HHV-8 Human herpes virus 8; HIV Human immunodeficiency virus; HTLV Human T-lymphotropic viruses; TTV Transfusiontransmitted virus; VCJD Variant Creutzfeldt-Jakob disease; WNV West Nile Virus

The estimated per unit risks of contamination in blood, blood products and manufactured plasma-derived products in Canada for a number of viral, bacterial, parasitic, prion and tick borne agents are presented in Tables 5 and 6 . Where Canadian data are not available, data from the United States and other countries have been included $(4,12,18-20)$. As the data in Tables 5 and 6 show, the risks in Canada of transmitting infectious agents by blood, and especially by plasma manufactured products, are extremely low. For context, a $1 / 3,000,000$ risk is similar to that of being hit by lightning.

The risk estimates for transmission of CMV remain complex (21). Although $40 \%$ to $70 \%$ of donors are CMV-positive, the risk of disease in nonimmunocompromised recipients is very low, while the risk of disease in immunocompromised patients is significant. For CMV seronegative recipients, the risk of CMV infection in solid organ transplant recipients and in bone marrow transplant recipients is $2 \%$ to $3 \%$ and $20 \%$ to
TABLE 6

Estimated risks of infectious agents in manufactured plasma-derived products

\begin{tabular}{|c|c|c|c|}
\hline Agents & $\begin{array}{l}\text { Historical evidence } \\
\text { of transmission from } \\
\text { plasma product }\end{array}$ & Pathogenic & $\begin{array}{l}\text { Canadian estimated } \\
\text { risk of contamination* }\end{array}$ \\
\hline \multicolumn{4}{|c|}{ Viruses for which all blood donors are tested } \\
\hline HIV & yes & yes & less than $1 / 10$ million \\
\hline $\mathrm{HCV}$ & yes & yes & less than $1 / 10$ million \\
\hline HBV & yes & yes & less than $1 / 10$ million \\
\hline HTLV types I, II & yes & yes & only theoretical risk \\
\hline \multicolumn{4}{|l|}{ Other viruses } \\
\hline CMV & no & yes & only theoretical risk \\
\hline Parvovirus B19 & yes & yes & $\begin{array}{l}\text { only theoretical risk if } \\
\text { heat inactivation; } \\
\text { otherwise } 1 / 100,000 \text { to } \\
1 / 1,000,000\end{array}$ \\
\hline WNV & no & yes & $\begin{array}{c}\text { much lower than } \\
1 / 100,000, \text { only } \\
\text { theoretical risk }\end{array}$ \\
\hline
\end{tabular}

\section{Parasites}

\begin{tabular}{|c|c|c|c|}
\hline Malaria & no & yes & only theoretical risk \\
\hline Chagas & no & yes & only theoretical risk \\
\hline Babesiosis & no & yes & only theoretical risk \\
\hline \multicolumn{4}{|l|}{ Prion } \\
\hline vCJD & unknown & yes & $\begin{array}{r}\text { theoretical risk of less } \\
\text { than } 1 / 100,000,000\end{array}$ \\
\hline
\end{tabular}

*Risk of contamination refers to the potential residual risk of infection from the listed organisms in plasma-derived products after proper screening and correct manufacturing processes have taken place. CMV Cytomegalovirus; HBV Hepatitis B virus; HCV Hepatitis C virus; HIV Human immunodeficiency virus; HTLV Human T-lymphotropic viruses; vCJD Variant Creutzfeldt-Jakob disease; WNV West Nile virus

$50 \%$, respectively. This risk can be decreased with selection for seronegative donors and/or the use of leukocyte depletion filters, eg, the estimated risk for a bone marrow transplant recipient is only $2.4 \%$ using a leukocyte depletion filter (13).

Although the risk of transmission of infectious agents through blood and plasma products is very low, the possibility of risk with a new or previously unrecognized agent is always present. Hence, a reassessment of the potential transfusion risk must be made when a new agent is discovered, as was done with the severe acute respiratory syndrome donor deferral program (22). Experience gained from hepatitis $\mathrm{C}$ and human immunodeficiency virus trace-back and look-back programs, where authorities have tried to trace transfusion recipients, has shown that many patients are unaware that they actually received a transfusion. No national electronic record of transfusions yet exists to facilitate any potential future tracing programs for a new transmittable agent. Therefore, it is important to make sure that transfused patients are aware that they received blood, blood products or manufactured plasmaderived products, and that the discharge or outpatient note adequately documents these transfusions and records the label code numbers for the specific products used.

Recently, a pilot project aimed at improving surveillance for adverse events with transfusion of blood and blood products (Transfusion Transmitted Injuries Surveillance System) was carried out by Health Canada and four provinces (British 
Columbia, Quebec, Nova Scotia and Prince Edward Island). This pilot has demonstrated the benefits of standardized case definitions, report forms, and the added value of electronic reporting for ease and timeliness of data analysis. The Transfusion Transmitted Injuries Surveillance System program

\section{REFERENCES}

1. Strong DM, Katz L. Blood bank testing for infectious diseases: How safe is blood transfusion? Trends Mol Med 2002;8:355-8.

2. Murphy WG. Disease transmission by blood products: Past, present and future. Pathophysiol Haemost Thromb 2002;32(Suppl 1):1-4.

3. Committee on Infectious Diseases and Immunization. Canadian Paediatric Society. Principal authors: MacDonald NE, Scott JW, Giulivi T. Transfusion and risk of infection in Canada. Paediatr Child Health 2003;8:135-7.

4. Blood Safety: Reducing the Risk of Transfusion-Transmitted Infections. Report of the Committee on Infectious Diseases, 25th edn. Elk Grove Village: American Academy of Pediatrics, 2000:88-97.

5. Peterson LR, Marfin AA, Gubler DJ. West Nile Virus. JAMA 2003;290:524-8.

6. Committee on Infectious Diseases and Immunization. Canadian Paediatric Society. Principal author: Moore D. West Nile virus mosquitoes no longer just an annoyance. Paedtr Child Health 2003;8:267-70.

7. Pealer LN, Marfin AA, Peterson LR, et al. Transmission of West Nile Virus through blood transfusion in the United States in 2002. N Engl J Med 2003;349:1236-45.

8. Biggerstaff BJ, Peterson LR. Estimated risk of transmission of the West Nile Virus through blood transfusion in the US, 2002. Transfusion 2003;43:1007-17.

9. West Nile Virus. Transmission through blood. Health Canada. <www.hc-sc.gc.ca/english/westnile/blood.html\#3> (Version current at February 12, 2004).

10. West Nile Monitor. West Nile virus surveillance information. Ottawa: Health Canada. <www.hc-sc.gc.ca/pphb-dgspsp/wnvvwn/index.html> (Version current at February 12, 2004).

11. Busch MP. Closing the windows on viral transmission by blood transfusion. In: Stramer SL, ed. Blood Safety in the New Millennium. Bethesda: American Association of Blood Banks, 2001.

12. Guertler LG. Virus safety of human blood, plasma, and derived products. Thromb Res 2002;107:S39-S45. has now been extended to four other provinces and is expected to be applied nationwide by 2006. When fully implemented, this program is expected to improve the quality and timeliness of risk estimates for blood related infectious diseases and injuries.

13. Laupacis A, Brown J, Costello B, et al. Prevention of posttransfusion CMV in the era of universal WBC reduction: A consensus statement. Transfusion 2001;41:560-9.

14. Blumel J, Schmidt I, Willkommen H, et al. Inactivation of parvovirus B19 during pasteurization of human serum albumin. Transfusion 2002;42:1011-8.

15. Blajchman MA. Incidence and significance of the bacterial contamination of blood components. Dev Biol 2002;108:59-67.

16. Seghatchian J. Bacterial contamination of blood components. Transfus Apharesis Sci 2001;25:147-50.

17. Churchill WH, Schmidt B, Lindsey J, et al. Thawing fresh frozen plasma in a microwave oven. A comparison with thawing in a 37 degrees $\mathrm{C}$ water bath. Am J Clin Pathol 1992;97:227-32.

18. Kleinman S, Chan P, Robillard P. Risks associated with transfusion of cellular blood products in Canada. Tranfus Med Rev 2003;17:120-62.

19. Chiavette J-A, Escobar M, Newman A, et al. Incidence and estimated rates of residual risk for HIV, hepatitis C, hepatitis B and human T-cell lymphotropic viruses in blood donors in Canada, 1990-2000. CMAJ 2003;169:767-73.

20. Tabor E. The epidemiology of virus transmission by plasma derivatives: Clinical studies verifying the lack of transmission of hepatitis B and C and HIV type 1. Transfusion 1999;39:1160-8.

21. Preksaitis JK, Sandu J, Strautman M. The risk of transmissionacquired CMV in seronegative solid-organ transplant recipients receiving non-WBC-reduced blood components not screened for CMV antibody (1984 to 1996): Experience at a single Canadian center. Transfusion 2002;42:396-402.

22. Protecting Canada's Blood Supply. Update $\# 30-$ Severe Acute Respiratory Syndrome. Ottawa: Health Canada <www.hcsc.gc.ca/english/protection/warnings/sars/update30.html> (Version current at February 12, 2004).

\section{CANADIAN PAEDIATRIC SOCIETY, INFECTIOUS DISEASES AND IMMUNIZATION COMMITTEE}

Committee Members: Drs Upton Allen, The Hospital for Sick Children, Toronto, Ontario; H Dele Davies, East Lansing, Michigan (USA); Simon Richard Dobson, BC's Children Hospital, Vancouver, British Columbia; Joanne Embree, The University of Manitoba, Winnipeg, Manitoba (Chair); Joanne Langley, IWK Health Centre, Halifax, Nova Scotia; Dorothy Moore, Montreal Children's Hospital, Montreal, Quebec; Gary Pekeles, The Montreal Children's Hospital, Montreal, Quebec (Board Representative)

Consultants: Dr Gilles Delage, Héma-Québec, Saint-Laurent, Quebec; Noni MacDonald, Dalhousie University, Halifax, Nova Scotia Liaisons: Drs Scott Halperin, IWK Health Centre, Halifax, Nova Scotia (IMPACT); Susan King, The Hospital for Sick Children, Toronto, Ontario (Canadian Paediatrics AIDS Research Group); Monica Naus, BC Centre for Disease Control, Vancouver, British Columbia; Larry Pickering, Centre for Disease Control and Prevention, Atlanta, Georgia (American Academy of Pediatrics)

Principal author: Drs Noni E Macdonald, Canadian Paediatric Society, Dalhousie University, Halifax, Nova Scotia; JW Scott, Department of Health, Halifax, Nova Scotia; A Giulivi, Centre for Infectious Disease Prevention and Control, Population and Public Health Branch, Health Canada, Ottawa, Ontario

The recommendations in this statement do not indicate an exclusive course of treatment or procedure to be followed. Variations, taking into account individual circumstances, may be appropriate. This article also appears in Paediatr Child Health 2004;9(3). 


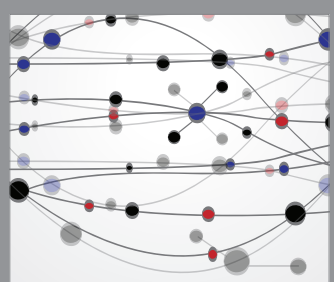

The Scientific World Journal
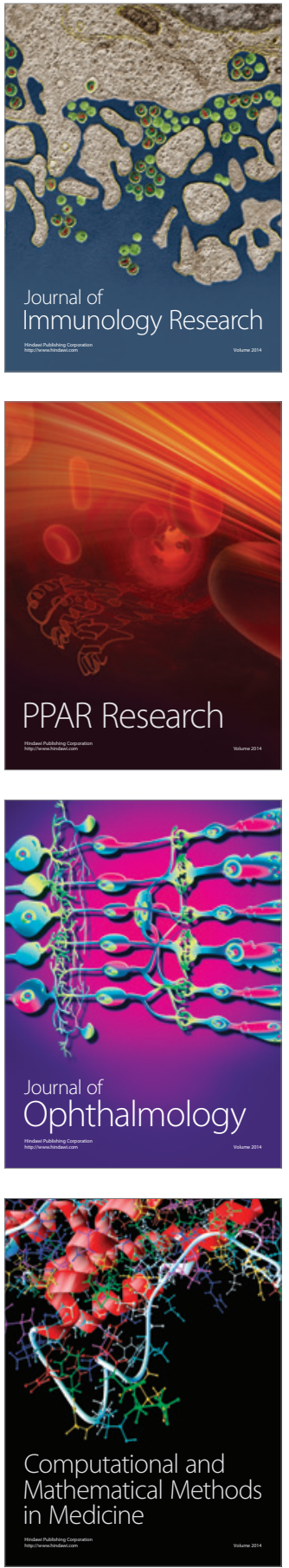

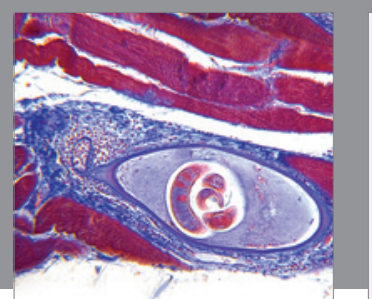

Gastroenterology Research and Practice

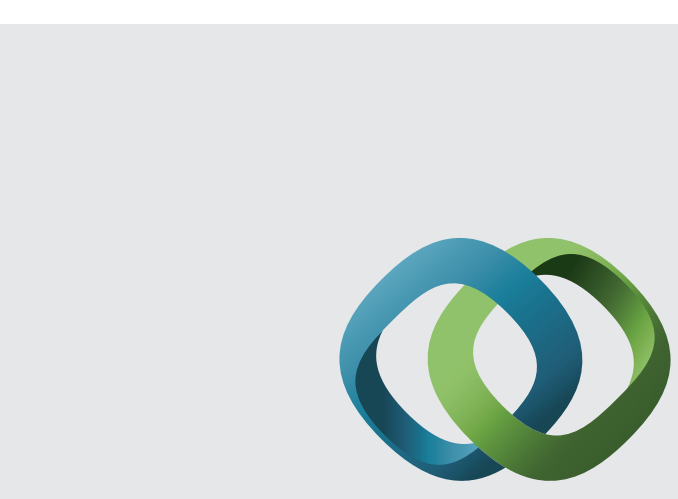

\section{Hindawi}

Submit your manuscripts at

http://www.hindawi.com
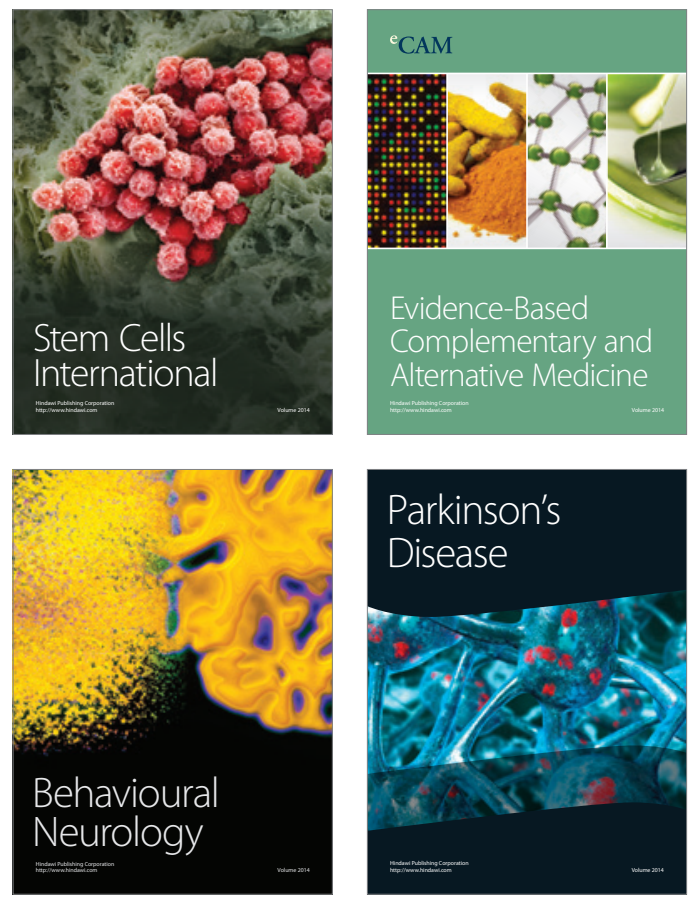
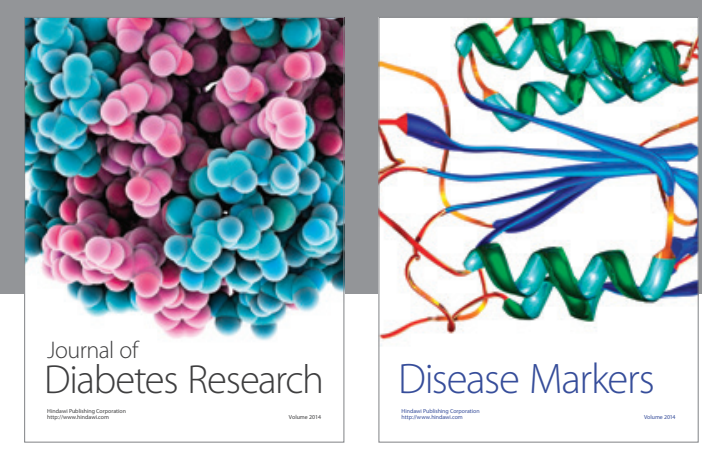

Disease Markers
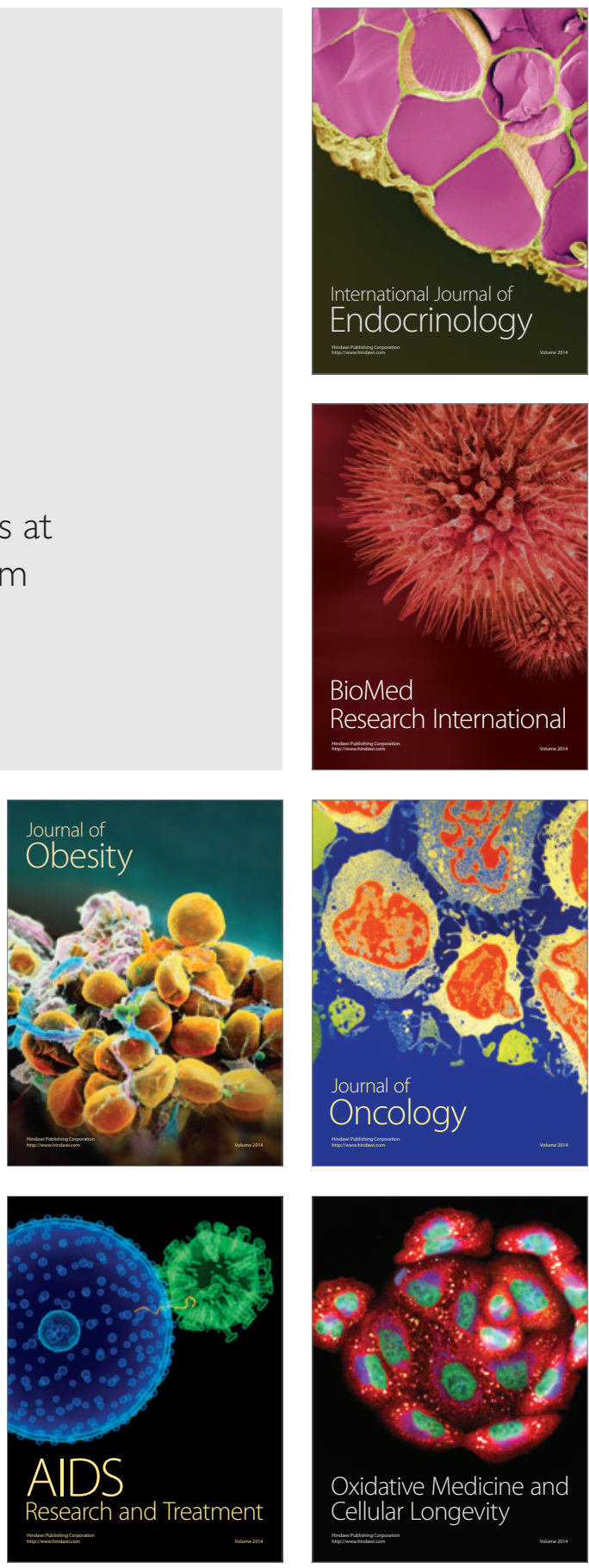